\title{
EDUCATION IN FURTHER PROFESSIONAL EDUCATION BEFORE AND DURING THE PANDEMIC
}

\author{
MARTA MATULČÍKOVÁ ${ }^{1}$ - DANIELA BREVENÍKOVÁ ${ }^{2}$
}

\section{Vzdelávanie v d'alšom profesijnom vzdelávaní pred pandémiou a počas pandémie}

\begin{abstract}
The aim of the paper is to increase the motivation of organisations by providing the varieties of forms of education and the possibility of choosing the form of education for a specific educational activity. The focus of the paper is on two basic forms of education, full-time and distance learning. The centre of our attention is distance education, in terms of the conditions and implementation aspects of electronic corporate education in the Slovak Republic. Two methods were used in the empirical research: the questionnaire method and the interview. Respondents were selected from two sections of the Statistical Classification of Economic Activities - NACE (Rev.), Section C and Section $G, 120$ respondents in each section. Despite the digitalisation of the economy and education, respondents as well as authors believe that in the future, the corporate education after the pandemic will return to full-time education and development of blended education.
\end{abstract}

Keywords: distance education, form of education, Fourth Industrial Revolution Industry 4.0, full-time education, further professional education, digital competences, information and communication technologies, online communication

JEL Classification: D83, I2, M5, M12

\footnotetext{
${ }^{1}$ Assoc. Prof. Ing. Marta Matulčíková, PhD., University of Economics in Bratislava, Slovak Republic; email: marta.matulcikova@euba.sk

${ }^{2}$ Assoc. Prof. Dr. Daniela Breveníková, CSc., University of Economics in Bratislava, Slovak

Republic; email: daniela.brevenikova@zoznam.sk
} 


\section{Introduction}

Needs in further professional education are derived from the changing conditions of work activities. The labour market has an interdependent relationship with the education market; these two markets develop independently but in synergy. The implementation of the Fourth Industrial Revolution, Industry 4.0 or its higher level, Society 5.0, not only results in changing conditions under which activities are performed, but it also affects non-working life. It is currently estimated that $90 \%$ of jobs need a certain level of digital skills (European Commission, 2021). The digital revolution also affects educational environment: the content of education is changing, providing the learners with professional knowledge needed for the application of new technologies and new techniques, the use of new materials, etc. Likewise, the technologies used in instruction are changing, especially from the aspect of the organizational aspect of education (Xu, David and Kim, 2018).

Digital competences, as part of the revised European Framework of Reference for Key Competences (European Commission, 2016) for lifelong learning, include the knowledge, skills, and approaches that all citizens need in the digital society. Digital competences involve a self-confident and professional use of digital technologies. The Digital Competence Framework for Citizens (European Commission, 2016) describes digital competences in the following five areas:

- information and data literacy,

- communication and collaboration,

- digital content creation,

- safety,

- problem solving.

A systematic support for digital competences is linked to developing models of digital competences, which are part of The European Framework for the Digital Competence of Educators (DigCompEdu) (European Commission, 2017). The digital revolution is dramatically changing our way of life, work but also study. On the one hand, this revolution brings huge opportunities; however, unless the digital competences develop, there may arise serious risks. This is also reflected in the field of education, where the need for continuing education can be fully carried out through the application of information and communication technologies in improved forms of education. 
The pandemic itself has also had an impact on the improvement of distant education forms (Li and Lalani, 2020; Lockee, 2021). Masters (2021) describes this as follows "The disruption to education, and to life itself, has been on a global scale and no-one has been left untouched in some way or other. For educators it has meant embracing online learning at an unprecedented rate, with institutions scrambling to put strategies in place to reach as many students as possible" (Masters, 2021, p.1). A significant shift has been recorded in the possibilities of using the online e-learning. Online platforms began to expand, allowing topics to be presented and discussed in the dialogue mode. Despite the fact that various forms of education are known in practice, in the paper we focus on two basic forms of education, namely full-time and distance learning. The centre of our attention is distance education, with focus on the analysis of conditions and implementation aspects of electronic business education in companies in the Slovak Republic.

European citizens of all age groups need to be equipped with digital skills; otherwise, there is a real danger that Europe is going to lose its greatest competitive advantage, i.e. qualified and educated human resources.

\section{State-of-the-art in the Development of Form of Education}

Employee education can be viewed as a specific area of adult education. A successful educational process requires a systemic approach and respect for its peculiarities and the application of the personality strengths of further education participants. Further professional education, its course and results are influenced by the motivation of its learners. Forms of education represent a relatively permanent and stable set of didactic and organizational measures, which implement education in a defined time, in a defined place, and in relation to living and non-living didactic systems (Barták, 2015). The concept of form in education involves the definition of the way of organizing education in relation to the number and composition of participants, the venue of education, in terms of time, repeatability, and the way of organizing the educators' and participants' activities (Mendíková, 2010). All attributes of the organizational aspect of education are reflected in the forms of education. The form of education represents the organizational side of education, and its choice depends on a number of factors that affect education. In our paper we will deal with forms of education, according to the way of organizing the activities of educators and participants in education. For this reason and also 
due to the limits on the length of the paper, some forms of education will not be described and analyzed in the paper.

The form of education differs in terms of the degree and nature of the lecturer's contact with the participant. On the one hand, there is a direct contact of the lecturer with the participant ofeducation - face-to-face instruction or fulltime education; on the other hand, there is an indirect contact of the lecturer with the participant, through information and communication technologies and technical support - distance education. The history of guided distance forms of education is associated with correspondence education. Nowadays, correspondence education is considered to be the first stage of distance education and also e-learning, supported by the development of information and communication technologies (Mužík, 2011; Encyclopedia Britannica, n.d.). Due to the length of the interaction between the learner and the educator, correspondent education is implemented only to a limited extent. It has been pushed into the background by better communication technologies. The development of information and communication technologies has made it possible for distance learning to assume the form of the dialogue model of e-learning. In the 1950-ies, various experiments occurred in computerbased education. In this instruction, computers were used to present teaching materials, which consisted of text, video, and audio for the assessment of learners' progress. Most of the primary research was conducted by IBM. This company applied elements of the latest cognitive science theories in the application of educational technologies (Arnold, 1997 - 2000; Johnston, 2016).

Another significant advance in educational technologies was connecting computers via the Internet. This progress has enabled the development of modern distance education. Current distance learning courses use a variety of web-based systems that include digital reading materials, podcasts, e-mail, chat rooms, discussion forums, and the like. Most systems are generally asynchronous and allow participants access to most functions whenever they need or want them. Likewise, synchronous technologies are used and include audio, live video, and shared access to electronic documents at scheduled times. Synchronous technologies enable us to bring distance education closer to the direct interaction between the educator and the learner. Instead of the direct physical contact, technologies allow the virtual contact between the lecturer and the learner. We can observe here a significant shift from the ideas presented by Keegan, Holmberg, Race, Moore, Saba and Twitchell (Keegan, 
1996; Race, 1998; Veteška and Vacinová, 2011), etc., who described distance education as learning at a distance, where the emphasis is on the time delay between the teaching process and the learning process. In this case, the basic principle of distance education was applied, namely the principle of independence and the principle of guidance (Veteška and Vacinová, 2011).

Neubauer of University of Hawai, Department of Political Science, deals with these principles from a broader perspective and lists the following three principles of distance education:

"(1) the principle of multiple modalities in which the author means not only the techniques but also the aesthetics and qualifying practices of distance education; (2) ensuring that distance education is neither independent nor in competition with traditional, campus-based classroom pedagogical techniques and orientations; and (3) seeking ways to create virtual communities of distance learners and tie them to those non-virtual communities that constitute the core of the university" (Neubauer, 2002, pp. 4-5).

Distance learning has been improved through the application of online communication platforms. In the present paper, we list some online platforms that have become a tool for education and enabled the substitution of full-time education with the distance form of education, however, not to a full extent, as the direct physical contact between the lecturer and the learner is impossible in the distance form.

Table 1: Examples of most frequently used online platforms in professional discussions and educational activities:

\begin{tabular}{|l|l|}
\hline Online platforms & Description \\
\hline Skype & $\begin{array}{l}\text { Skype assists individuals all over the world to } \\
\text { conduct conversations. It offers services such as } \\
\text { messages, voice calls or video. }\end{array}$ \\
\hline Microsoft Teams & $\begin{array}{l}\text { Microsoft Teams enables to provide a wide range } \\
\text { of learning options through video calls with an } \\
\text { individual or a group, to quickly pass from the group } \\
\text { chat to video call, securely connect, access files, } \\
\text { share content, all of these in real time. It also offers } \\
\text { the feature of note making, creating documents, and } \\
\text { a calendar in one place. }\end{array}$ \\
\hline
\end{tabular}




\begin{tabular}{|c|c|}
\hline Zoom & $\begin{array}{l}\text { Zoom is an application that also offers services such } \\
\text { as calls, video calls, chats, and webinars. In addition, } \\
\text { unlike other applications, it also has a Marketplace } \\
\text { or On zoom application. It enables communication } \\
\text { with up to a thousand users simultaneously. Apart } \\
\text { from that, it has functions suitable for online } \\
\text { teaching. }\end{array}$ \\
\hline Hangouts Meet & $\begin{array}{l}\text { It is a platform created by Google. The transfer } \\
\text { of Meet video conferencing data is encrypted, } \\
\text { and an increased level of protection is ensured by } \\
\text { constantly updated security measures. It offers } \\
\text { options of meetings from any location, namely from } \\
\text { any device, screen sharing, phone connection, or } \\
\text { the broadcasting of internal events. }\end{array}$ \\
\hline Frello & $\begin{array}{l}\text { Frello is a Czech tool used for professional } \\
\text { discussions as well as work communication. It is } \\
\text { offered in the Czech language; it has a user-friendly } \\
\text { clear control and a simple customer support. It offers } \\
\text { services such as fast communication, calendar, } \\
\text { unification of client communication, and a lot of } \\
\text { other features. }\end{array}$ \\
\hline Webex Meetings & $\begin{array}{l}\text { Cisco Webex Meetings provides state-of-the-art } \\
\text { video and audio conferencing with features, sharing, } \\
\text { chat, and more. It is an important videoconferencing } \\
\text { tool. It represents an optimal solution for work at } \\
\text { distance and also for distance learning; it allows } \\
\text { users to create a virtual classroom, supports } \\
\text { interactive learning using audio, video, application } \\
\text { sharing, multimedia content, annotations, etc. The } \\
\text { virtual lesson takes place in a virtual classroom. HD } \\
\text { audio and video transforms virtual classrooms into } \\
\text { realistic experiences for students and lecturers. } \\
\text { It offers problem-free collaboration, integration } \\
\text { with various devices, as well as integration with } \\
\text { LMS. If the institution uses Moodle, Blackboard, } \\
\text { Sakai, Canvas or D2L, Webex can be integrated } \\
\text { into its learning management system. }\end{array}$ \\
\hline
\end{tabular}




\begin{tabular}{|l|l|}
\hline & $\begin{array}{l}\text { It offers flexibility, inclusiveness, security and } \\
\text { organization, and support. } \\
\text { At the same time, it has advantages such as } \\
\text { background noise removal, responsiveness, content } \\
\text { sharing, messages, calls and the like. }\end{array}$ \\
\hline Forkplace from & $\begin{array}{l}\text { It is a communication tool used in project solutions, } \\
\text { education as well as in the work process. It } \\
\text { enables communication with various employees }\end{array}$ \\
in the company and also outside the company; \\
it has various functions, for instance groups, \\
chat, live broadcasting, etc. External enterprise \\
communication is suitable for discussions and \\
team education. The automatic translation function \\
enables non-English speaking participants to take \\
part in projects and team learning.
\end{tabular}

Source: processed on the basis of business discussions and information on the application of online platforms (Skype, Google, Microsoft Teams, ZOOM Cloud meetings)

E-learning is a current technological element in distance education. However, it can also be applied in full-time education, where it creates multimedia and didactic support of the educational process to achieve higher quality and efficiency of education.

The development of information and communication technologies has made it possible to extend the guidance principle and distance learning support services for self-study participants with elements of full-time education and to ensure the direct interaction between the participant and the teacher. E-learning exists in several basic variants depending on the communication technology it uses (Clark and Mayer, 2016). It is basically divided into off-line and on-line e-learning.

Off-line e-learning does not require the connection of the student's computer to another computer via a real-time network. Study materials are distributed through storage media such as CD-ROM and DVD-ROM, HDD or LAN; they can also be tutorials delivered via the Internet WBT - i.e. Web Based Training (WBT), also Audio / Video and Computer Based Training (CBT). This type of education is advantageous for further education, where the student is engaged 
in independent study and combines home study with consultations with the lecturer. Off-line e-learning is a set of technological tools - hardware and software, supporting self-study.

Today, online e-learning is a very popular multimedia form of guided education. On-line e-learning is characteristic of its connectivity of computers in the network, through which information is transmitted, and based on that, the participants are connected (Hroník, 2007; Armstrong and Taylor, 2015). This is the kind of education that needs for its operation a computer network, either local - intranet or the global one - the Internet. Learners have access to educational content, i.e. digital scripts and an archive of animations, a library of electronic educational objects, and other materials for study (materials are stored, e.g., on Google Disc, Dropbox, etc). Online e-learning exists in two basic forms of communication, namely synchronous and asynchronous (Zlámalová, 2008).

The synchronous version of online e-learning requires a constant connection to the network and allows the student to be connected to the lecturer (tutor) and to their student colleagues at the given moment. Connection with the lecturer and colleagues is possible in realtime, not in space. Here, time independence is lost (Elkins and Pinder, 2015; Lee and Kim, 2020), but its great advantage is the ability to communicate over long distances, using chat, virtual telephone, interactive video, video conferencing service, etc.

The asynchronous format is less demanding as it does not need the permanent logging to the computer network. Learners communicate with their tutor via standard email, web, Skype consultations, discussion forums, and the like (Pomffyová, 2009). The following are the diverse forms of asynchronous communication:

- discussion forum,

- virtual seminar,

- computer simulations in a virtual lab,

- group project,

- e-mail, etc.

Learners are not under time pressure and can better formulate their ideas. Resources of asynchronous communication include: e-mail, e-mailing lists, newsgroups, message boards, discussion forums, and other short news programs. 
A clear and concise explanation of the benefits and limitations of applying asynchronous and synchronous e-learning in education is presented by Hrastinski (2008).

Table 2: When, Why, and How to Use Asynchronous vs. Synchronous E-Learning

\begin{tabular}{|c|c|c|}
\hline & Asynchronous e-learning & Synchronous e-learning \\
\hline When? & $\begin{array}{l}\text { Reflecting on complex issues. } \\
\text { When synchronous meetings } \\
\text { cannot be scheduled because } \\
\text { of work, family, and other } \\
\text { commitments. }\end{array}$ & $\begin{array}{l}\text { Discussing less complex } \\
\text { issues. Getting acquainted. } \\
\text { Planning tasks. }\end{array}$ \\
\hline Why? & $\begin{array}{l}\text { Students have more time to } \\
\text { reflect because the sender } \\
\text { does not expect an immediate } \\
\text { answer. }\end{array}$ & $\begin{array}{l}\text { Students become more } \\
\text { committed and motivated } \\
\text { because a quick response is } \\
\text { expected. }\end{array}$ \\
\hline How? & $\begin{array}{l}\text { Use asynchronous means such } \\
\text { as e-mail, discussion boards, } \\
\text { and blogs }\end{array}$ & $\begin{array}{l}\text { Use synchronous means } \\
\text { such as videoconferencing, } \\
\text { instant messaging and chat, } \\
\text { and complement with face- } \\
\text { to-face meetings. }\end{array}$ \\
\hline Examples & $\begin{array}{l}\text { Students are expected to } \\
\text { reflect individually on course } \\
\text { topics and may be asked to } \\
\text { maintain a blog. } \\
\text { Students are expected to share } \\
\text { reflections regarding course } \\
\text { topics and critically assess } \\
\text { their peers' ideas may be } \\
\text { asked to participate in online } \\
\text { discussions on a discussion } \\
\text { board. }\end{array}$ & $\begin{array}{l}\text { Students (are) expected } \\
\text { to work in groups may } \\
\text { be advised to use instant } \\
\text { messaging as support for } \\
\text { getting to know each other, } \\
\text { exchanging ideas, and } \\
\text { planning tasks. } \\
\text { A teacher who wants to } \\
\text { present concepts from the } \\
\text { literature in a simplified way } \\
\text { might give an online lecture } \\
\text { by videoconferencing. }\end{array}$ \\
\hline
\end{tabular}

Source: Hrastinski (2008, p.54) 
In Hrastinski's comparison of advantages and disadvantages of using the two versions of e-learning, the content is divided into sections relating to time (when), reason (why), and the way of application (how). To indicate the connection with the aim of our paper, i.e. focus on learner motivation, we have highlighted one phrase in the text of the table.

The use of information and communication technologies in education has a great future. It is also associated with the development of software products that offer automatic support for the learning process. These are the LMS (Learning Management System) and LCMS (Learning Content Management System) products. The original functions of LMS systems were focused only on the management and organization of teaching, but later functions were added for content management, synchronous and asynchronous communication options, authoring tools, and the functionality of the systems increased (Cooke, 2021; Irlbeck and Mowa, 2007; Trentin, 2010).

The market in educational technologies is growing fast and is full of innovative products. We can state nowadays that one of the least understood teaching/instruction technologies is Learning Content Management Systems (LCMS). Despite the fact that this platform enables to create, administer, host, and monitor digital educational content, it does not belong to systems frequently used in corporate training; for this reason, it will not be analysed in our empirical research. Present-day educational technologies are a significant advancement from the correspondence education; however, it is not desirable to suppress other beneficial forms of education by the massive development of information and communication technologies, in our opinion.

Opinions on the impact of the pandemic on education vary: While some believe that "the unplanned and rapid move to online learning - with no training, insufficient bandwidth, and little preparation - will result in a poor user experience that is unconducive to sustained growth, others believe that a new hybrid model of education will emerge, with significant benefits" (Li and Lalani, 2020).

\section{Research Design}

A survey of knowledge from domestic and foreign sources, we presented in the current state of development of guided forms of education, formed the basis of our empirical research. We investigated the possibilities of increasing 
the interest in further professional corporate education and are fully aware of the limitations involved: the motivation for further professional education can be influenced by a number of factors that cannot be fully described and analysed in the presented paper.

The aim of the paper is to increase the motivation of organisations by providing the varieties of forms of education and the possibility of choosing the right form of education for a specific educational activity. The Covid-19 pandemic has significantly affected and even transformed the usability of managed forms of education.

The research consisted of three main stages (Figure 1). In the first stage, we focused on the study of scientific and professional literature with the emphasis on managed form of education, i.e. full-time and distance learning. The development of information and communication technologies has improved the usability of distance education - the focus of our paper. In the second stage, we formulated research assumptions. In the third one, we evaluated the results of empirical research and proposed ways to increase the interest in further professional training in companies by applying the required forms of education.

Figure 1: Research Framework

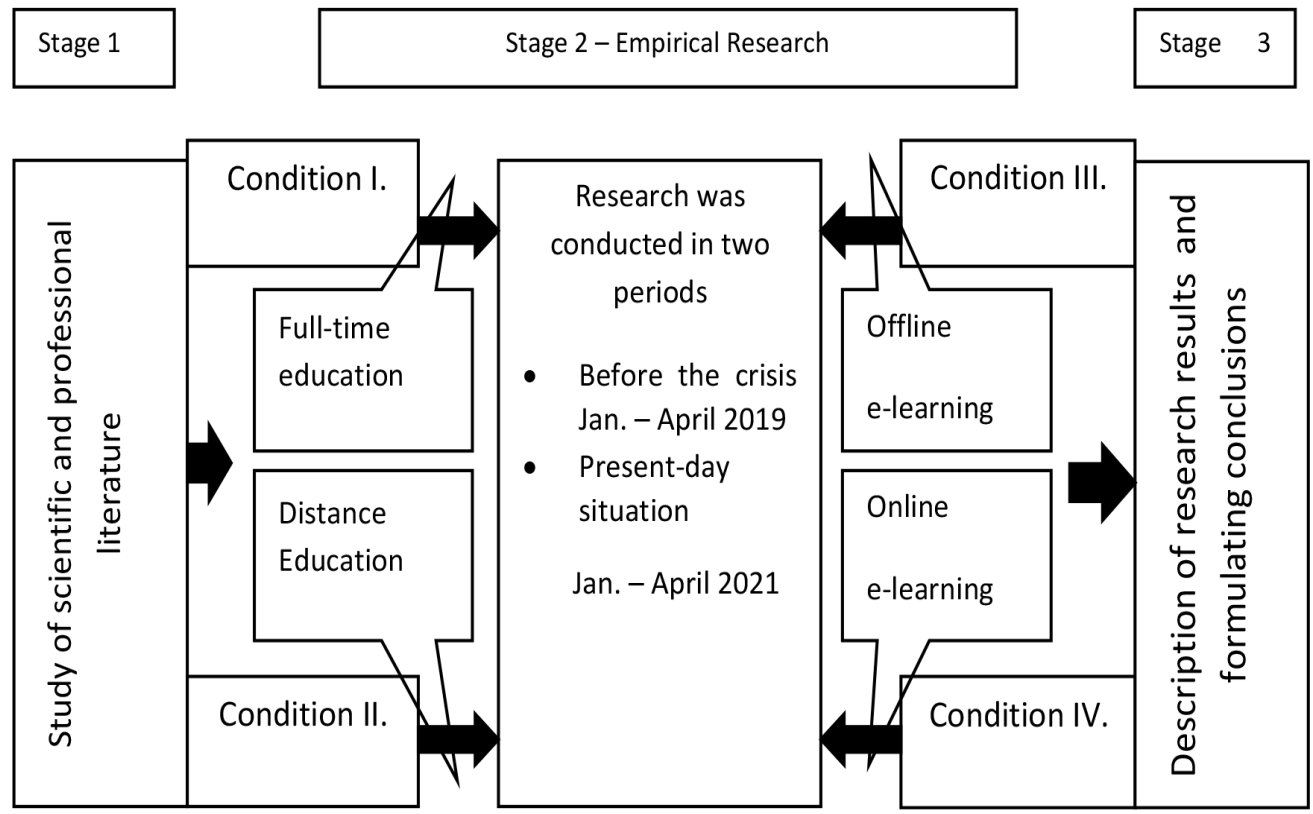

Source: prepared by authors 
In the research, we identified the impacts of applying various forms of education on the interest in participating in educational activities. The metric we have chosen when evaluating the scope of education are hours related to various forms of education.

The research was carried out by means of the interview method and the questionnaire method. The interview was used in order to better understand the respondents' opinions and experiences and was applied in the implementation of the pre-research and in designing the questionnaire. The questionnaire method was used for practical reasons: the research required the provision of a representative sample of respondents, and this method makes it possible to collect data from a larger number of respondents within a reasonable time and at a reasonable cost. Questionnaires were distributed in person or electronically. The questionnaire consisted of two parts: the information part containing the basic data about the respondents and the professional part concerning the respondents' opinions on the implementation of education/training in their companies and the general interest of employees in participating in the training. Primary data were collected on the basis of questions from a questionnaire prepared in advance. During the research, some respondents withdrew from the research project, and some questionnaires were not taken into account as they were not fully completed. For the implementation of the research, the opinions of respondents representing the production and non-production spheres were considered.

Respondents were selected at random, from all size categories of companies, while we took into account only the number of employees in the company. According to the Statistical Classification of Economic Activities SK NACE Rev. 2 production sphere was represented by Section $\mathrm{C}$ - Industrial production (EUROSTAT, 2020, 2021). The non-production sphere and services were represented by the opinions of respondents from Section $\mathrm{G}$ - Wholesale and retail trade; repair of motor vehicles and motorcycles. We believe that empirical research is applicable in all the sectors listed in the sectoral classification of economic activities, which were gradually carried out. The total number of respondents as determined was 240; we considered proportionality: 120 respondents in each section. The time devoted to the interview lasted longer than we had planned, as we really intended to have 120 respondents from each section. The survey ended in the given section after reaching the given number of respondents. The interviewed respondents were personnel managers and line managers, or owners, mainly of small businesses. We selected the research 
sample at random, so that the results were not distorted by a biased selection. During the implementation of the research, we formulated the following research assumptions:

I. Distance education increases the range of hours of education.

II. E-learning used in distance education is applied mainly in the offline variant.

III. In the online variant of education, asynchronous education in the company is preferred.

IV. The company is more interested in synchronous education compared to full-time education.

Individual respondents from companies form statistical units, and their opinions form the basis for the application of selected statistical methods that enable us to evaluate the analyzed issues. We used the method of descriptive statistics to evaluate the research results. Two types of methods were used for statistical processing of the collected information:

manual processing (the bar code method has been applied for some types of questions); and automated processing (we analyzed the collected data in MS Excel) (Chajdiak, 2009).

The results of statistical processing are presented in statistical surveys in tables and in verbal description of the knowledge acquired.

\section{Research Results}

The development and improvement of information and communication technologies creates opportunities for improving forms of education. Digitalisation affects not only the world of business but also the world of education. Information and communication technologies have significantly influenced the area of business education during the pandemic. We describe this development trend in our empirical research. 
Table 3: Length of full-time and distance education (in hours) of technical employees and specialists in Section C - Industrial production

\begin{tabular}{|c|c|c|c|c|c|c|}
\hline \multirow[t]{2}{*}{$\begin{array}{c}\text { Code } \\
\text { for the } \\
\text { needs of } \\
\text { statistical } \\
\text { processing }\end{array}$} & \multirow[t]{2}{*}{$\begin{array}{c}\text { Employee } \\
\text { instruction } \\
\text { (training) } \\
\text { in hours/ } \\
\text { month }\end{array}$} & \multirow[t]{2}{*}{$\begin{array}{c}\text { Basic forms } \\
\text { of managed } \\
\text { education }\end{array}$} & \multicolumn{2}{|c|}{$\begin{array}{l}\text { Number of } \\
\text { respondents in } \\
\text { absolute figures }\end{array}$} & \multicolumn{2}{|c|}{$\begin{array}{c}\text { Scope of } \\
\text { education } \\
\text { from average } \\
\text { number of hours } \\
\text { in hours }\end{array}$} \\
\hline & & & $\begin{array}{c}\text { Before } \\
\text { the } 2019 \\
\text { crisis }\end{array}$ & $\begin{array}{c}\text { At } \\
\text { present } \\
\mathbf{2 0 2 1}\end{array}$ & $\begin{array}{l}\text { Before } \\
\text { the } \\
2019 \\
\text { crisis }\end{array}$ & $\begin{array}{c}\text { At } \\
\text { present } \\
2021\end{array}$ \\
\hline \multirow[t]{2}{*}{1} & \multirow[t]{2}{*}{$1-5 \mathrm{~h}}$. & Full-time education & 32 & 3 & 96 & 9 \\
\hline & & Distance education & 41 & 98 & 123 & 294 \\
\hline \multirow[t]{2}{*}{2} & \multirow[t]{2}{*}{$6-10 \mathrm{~h}}$. & Full-time education & 74 & 0 & 568 & 0 \\
\hline & & Distance education & 14 & 19 & 112 & 152 \\
\hline \multirow[t]{2}{*}{3} & \multirow[t]{2}{*}{$11-20 \mathrm{~h}}$. & Full-time education & 9 & 0 & 139.5 & 0 \\
\hline & & Distance education & 8 & 3 & 124 & 46.5 \\
\hline \multirow[t]{2}{*}{4} & \multirow[t]{2}{*}{$21-30 \mathrm{~h}}$. & Full-time education & 5 & 0 & 127.5 & 0 \\
\hline & & Distance education & 0 & 0 & 0 & 0 \\
\hline \multirow[t]{2}{*}{5} & \multirow[t]{2}{*}{$31-40 \mathrm{~h}}$. & Full-time education & - & - & - & - \\
\hline & & Distance education & - & - & - & - \\
\hline \multirow[t]{4}{*}{6} & \multirow{2}{*}{$\begin{array}{l}\text { The } \\
\text { forms of } \\
\text { education } \\
\text { are not } \\
\text { applied. }\end{array}$} & Full-time education & - & 117 & - & - \\
\hline & & Distance education & 57 & - & - & - \\
\hline & \multirow[t]{2}{*}{ Total } & Full-time education & 120 & 120 & 931 & $9 \mathrm{~h}$. \\
\hline & & Distance education & 120 & 120 & 359 & $492.5 \mathrm{~h}$. \\
\hline
\end{tabular}

Note: The research was conducted during the same period in both years: January - April 2019; January - April 2021.

In 2019, all analysed companies in Section C took part in full-time education; distance education was used in 63 companies within further corporate education. Due to the Covid-19 pandemic only three companies used full-time education in 2021, while the number of hours of education was low. Other companies focused on distance education. When comparing the number of hours of education in 2019 and 2021, a large decrease can be observed. While in 2019 the number of hours of education (both full-time and distance) was 1290 , in 2021 it was 501.5 hours, which represents a decrease of about $61 \%$. 
The highest increase in distance education was up to five hours, which was mainly connected with occupational safety and health training.

Table 4: Length of full-time and distance education in hours of sales representatives and employees in services in Section $\mathrm{G}-$ Wholesale and retail trade; repair of motor vehicles and motorcycles.

\begin{tabular}{|c|c|c|c|c|c|c|}
\hline \multirow{2}{*}{$\begin{array}{c}\text { Code } \\
\text { for the } \\
\text { needs of } \\
\text { statistical } \\
\text { processing }\end{array}$} & \multirow{2}{*}{$\begin{array}{c}\text { Employee } \\
\text { instruction } \\
\text { (training) } \\
\text { in hours/ } \\
\text { month }\end{array}$} & \multirow[t]{2}{*}{$\begin{array}{l}\text { Basic forms of } \\
\text { guided education }\end{array}$} & \multicolumn{2}{|c|}{$\begin{array}{l}\text { Number of } \\
\text { respondents in } \\
\text { absolute figures }\end{array}$} & \multicolumn{2}{|c|}{$\begin{array}{c}\text { Totals } \\
\text { from average } \\
\text { number of hours } \\
\text { in hours }\end{array}$} \\
\hline & & & $\begin{array}{c}\text { Before } \\
\text { the } 2019 \\
\text { crisis }\end{array}$ & $\begin{array}{c}\text { At } \\
\text { present } \\
2021\end{array}$ & $\begin{array}{c}\text { Before } \\
\text { the } \\
2019 \\
\text { crisis }\end{array}$ & $\begin{array}{c}\text { At } \\
\text { present } \\
\mathbf{2 0 2 1}\end{array}$ \\
\hline \multirow[t]{2}{*}{1} & \multirow[t]{2}{*}{$1-5 \mathrm{~h}}$. & Full-time education & 23 & 16 & 69 & 48 \\
\hline & & Distance education & 9 & 89 & 27 & 267 \\
\hline \multirow[t]{2}{*}{2} & \multirow[t]{2}{*}{$6-10 \mathrm{~h}}$. & Full-time education & 82 & 0 & 659 & 0 \\
\hline & & Distance education & 23 & 18 & 184 & 144 \\
\hline \multirow[t]{2}{*}{3} & \multirow[t]{2}{*}{$11-20 \mathrm{~h}}$. & Full-time education & 7 & 0 & 108.5 & 0 \\
\hline & & Distance education & 6 & 9 & 93 & 139.5 \\
\hline \multirow[t]{2}{*}{4} & \multirow[t]{2}{*}{$21-30 \mathrm{~h}$} & Full-time education & 8 & 0 & 204 & 0 \\
\hline & & Distance education & 3 & 4 & 76.5 & 102 \\
\hline \multirow[t]{2}{*}{5} & \multirow[t]{2}{*}{$31-40 \mathrm{~h}}$. & Full-time education & 0 & 0 & 0 & 0 \\
\hline & & Distance education & 0 & 0 & 0 & 0 \\
\hline \multirow[t]{4}{*}{6} & \multirow{2}{*}{$\begin{array}{l}\text { The } \\
\text { forms of } \\
\text { education } \\
\text { are not } \\
\text { applied. }\end{array}$} & Full-time education & 0 & 104 & - & - \\
\hline & & Distance education & 79 & 0 & - & - \\
\hline & \multirow[t]{2}{*}{ Total } & Full-time education & 120 & 120 & $1037.5 \mathrm{~h}$. & $48 \mathrm{~h}$. \\
\hline & & Distance education & 120 & 120 & $380.5 \mathrm{~h}$. & $652.5 \mathrm{~h}$. \\
\hline
\end{tabular}

Source: results of empirical research (120 respondents, full-time and distance education are separately evaluated, many businesses also use a combination of full-time and distance education.)

Note: The research was conducted during the same period in both years: January - April 2019; January - April 2021.

Empirical research confirmed that in Section G, a considerable attention was paid to the education of the analysed group of employees. Although distance learning in 2019 was not implemented by almost $66 \%$ of organizations, a 
significant number of hours of full-time education war provided. In 2021, small-scale education was also provided as full-time education (up to 5 hours/ month), but the focus was on distance education. It means that $7 \%$ of education was full-time and $93 \%$ as distance education.

It is interesting to note that Section $\mathrm{G}$, compared with Section $\mathrm{C}$, provided more training activities in 2019 and also in 2021, in terms of the number of training hours spent by employees. This was justified by new products, which include the object of sale, new technologies and digitalisation of operations, requirement for increasing the quality of services provided, communication with customers, the speed of processing their needs, handling complaints, etc.

Since the full-time form of education is of a long-term nature, in the research we focused on the implementation of distance education.

Table 5: Preferred variants in e-education - Section C: Industrial production

\begin{tabular}{|c|c|c|c|c|}
\hline \multirow[t]{2}{*}{$\begin{array}{l}\text { Variant of } \\
\text { education }\end{array}$} & \multirow[t]{2}{*}{$\begin{array}{c}\text { Items } \\
\text { supported }\end{array}$} & \multirow[t]{2}{*}{ Tools applied } & \multicolumn{2}{|c|}{$\begin{array}{c}\text { Section C } \\
\text { Statistical Classification } \\
\text { of Economic Activities } \\
\text { (NACE Rev.2) }\end{array}$} \\
\hline & & & $\begin{array}{l}\text { Year } 2019 \\
\text { (63 respon- } \\
\text { dents) }\end{array}$ & $\begin{array}{c}\text { Year } 2021 \\
(120 \text { re- } \\
\text { spondents })\end{array}$ \\
\hline \multirow[t]{2}{*}{$\begin{array}{l}\text { Offline } \\
\text { education }\end{array}$} & $\begin{array}{l}\text { CBT }- \\
\text { Computer } \\
\text { Based } \\
\text { Training)* } \\
\end{array}$ & $\begin{array}{c}\text { Training materials on CD and } \\
\text { DVD }\end{array}$ & 8 & 6 \\
\hline & $\begin{array}{l}\text { WBT - } \\
\text { Web Based } \\
\text { Training** }\end{array}$ & $\begin{array}{l}\text { Training materials are on Web- } \\
\text {-pages and are available through } \\
\text { Web browsers. }\end{array}$ & 37 & 37 \\
\hline \multirow[t]{2}{*}{$\begin{array}{c}\text { Online } \\
\text { education }\end{array}$} & $\begin{array}{l}\text { Asynchronous } \\
\text { version }\end{array}$ & $\begin{array}{l}\text { Tools used in training: electro- } \\
\text { nic mailing of training mate- } \\
\text { rials, electronic mail, discussion } \\
\text { forums, visiting e-libraries, } \\
\text { portals, social networks, etc. }\end{array}$ & 18 & 19 \\
\hline & $\begin{array}{l}\text { Synchronous } \\
\text { version }\end{array}$ & $\begin{array}{l}\text { Audio, video tools, internet } \\
\text { telephony, lecture transmissions } \\
\text { with dialogue options videocon- } \\
\text { ferences, chats, etc. }\end{array}$ & 0 & 58 \\
\hline
\end{tabular}

Source: results of empirical research (Respondents listed preferred and favourite tools of education.) 
Table 6: Preferred e-variants in education - Section G: Wholesale and Retail; motor vehicles and motorcycle repair

\begin{tabular}{|c|c|c|c|c|}
\hline \multirow[t]{2}{*}{$\begin{array}{l}\text { Variant of } \\
\text { education }\end{array}$} & \multirow[t]{2}{*}{$\begin{array}{c}\text { Items } \\
\text { supported }\end{array}$} & \multirow[t]{2}{*}{ Tools applied } & \multicolumn{2}{|c|}{$\begin{array}{c}\text { Section C } \\
\text { Statistical Classification of } \\
\text { Economic Activities }\end{array}$} \\
\hline & & & $\begin{array}{c}\text { Year } \\
2019(41 \\
\text { respondents })\end{array}$ & $\begin{array}{c}\text { Year } \\
2021(120 \\
\text { respondents })\end{array}$ \\
\hline \multirow[t]{2}{*}{$\begin{array}{l}\text { Offline } \\
\text { education }\end{array}$} & $\begin{array}{l}\text { CBT - } \\
\text { Computer } \\
\text { Based } \\
\text { Training)* }\end{array}$ & $\begin{array}{l}\text { Training materials on CD } \\
\text { and DVD disks }\end{array}$ & 7 & 4 \\
\hline & $\begin{array}{l}\text { WBT - } \\
\text { Web Based } \\
\text { Training** }\end{array}$ & $\begin{array}{c}\text { Training materials are on } \\
\text { Web-pages } \\
\text { and are available by } \\
\text { means of Web browsers. }\end{array}$ & 18 & 8 \\
\hline \multirow[t]{2}{*}{$\begin{array}{l}\text { Online } \\
\text { education }\end{array}$} & $\begin{array}{l}\text { Asynchronous } \\
\text { version }\end{array}$ & $\begin{array}{l}\text { Tools used in education: } \\
\text { education materials } \\
\text { dispatched by email, } \\
\text { electronic mail, } \\
\text { discussion forums, visits } \\
\text { to e-libraries, portals, } \\
\text { social networks, etc. }\end{array}$ & 11 & 39 \\
\hline & $\begin{array}{l}\text { Synchronous } \\
\text { version }\end{array}$ & $\begin{array}{l}\text { Audio, video tools, } \\
\text { internet telephony, lecture } \\
\text { transmissions with non- } \\
\text { feedback and feedback } \\
\text { options, etc. }\end{array}$ & 5 & 69 \\
\hline
\end{tabular}

Source: results of empirical research (respondents listed preferred and favourite tools of education)

Notes on Tab. 5 and Tab. 6:

* Educational materials are presented in a computer; they primarily come from CD or DVD disks, while the computer does not have to be linked to the Internet. For this reason, educational materials do not contain links to external sources. They contain the following supported items: Computer tests, Simulations, Animations, Video, Audio, Pictures, and Texts.

**Educational materials are located primarily on the Website. The Internet and the Web bring increased interactivity, hyperlinks and electronic communication capabilities to WBT. The content includes the following supported items: teamwork, video conferencing, chat discussion forums, online tests, e-mail, and hyperlinks.

In education, companies preferred offline education in 2019 and the asynchronous version of online education, but in Section $\mathrm{G}$ synchronous tools of online education were also used, and communication was conducted via 
the broadcast model when the instructor/teacher delivers the learning content without regard to feedback from the learners. The pandemic has resulted in transferring the features of full-time learning to synchronous online learning tools. In Section C, the opinions of the respondents fully confirmed this, and in Section $\mathrm{G}$ there was also a higher use of tools in the asynchronous version of education. The increase in the use of platforms in synchronous education is considerable. The use of online platforms is shown in Tab. 7.

Table 7: Online platforms used in 2021 in Sections C and G (NACE Rev.2)

\begin{tabular}{|l|c|c|}
\hline \multirow{2}{*}{ Online platforms } & \multicolumn{2}{|c|}{ Synchronous learning } \\
\cline { 2 - 3 } & Section C (58 users) & Section G (69 users) \\
\hline Skype & 3 & 11 \\
\hline ZOOM & 6 & 4 \\
\hline Frello & 7 & 0 \\
\hline Webex Meetings & 18 & 23 \\
\hline Workplace from Facebook & 24 & 31 \\
\hline
\end{tabular}

Source: Results of empirical research (Respondents stated preferred and favourite instruments in education.)

In Table 7 we have listed the most frequently used online platforms, which does not mean that companies do not occasionally use other platforms in their offers of educational activities.

If the training is provided on a supplier basis at a given educational institution, usually the institution uses its platform for providing its educational services.

\section{Discussion and Proposals for the Improvements in Applying Forms of Education in Businesses}

The form of education used in the company can be a strong motivator for employees to learn. The choice of forms of education depends not only on the content of education, the lecturer's preferences, but also on the needs of employees and their abilities to participate in various forms of education.

Distance education has always been the preferred form of education, owing to the freedom in access to education, where the emphasis is mainly on individual 
learning and the possibility of individual acquisition of the learning content. Based on the results of the research, we can state that distance education does not result in higher learning hours so as to ensure widely available continuing education. The possibility of learning directly from the workplace or even from home does not increase the hours of learning, either. Although there are already numerous usable versions of distance education today, there were no opinions expressed in the empirical research that it should replace full-time education. Full-time education has remained the preferred form of education. In our opinion, based on research findings and observation, once the covid pandemic measures become relaxed, the full-time education will certainly be restored to almost its original extent. Offline education during the pandemic was the most widely used variant of e-learning, mainly Web-based Training (WBT).

In some companies, the asynchronous communication technology was used in e-learning, which offers more options. The discussion forum allows employees and lecturers (managers) to share their ideas, ask questions, and show individual discoveries whenever they want and from any place with an internet connection. The discussion is organized in thematic groups, i.e. posts related to a certain topic are displayed together. Unlike passive reading of a website, the discussion forum is based on the active participation of its users. Links can also be used in posts, which allow users to include nontextual information (e.g. pictures). By entering the e-mail address, one-to-one communication is also possible. After the lecturer or the manager has set up a discussion forum, they can fully administer it (Krishnan and Rogers, 2015; De Lima, et al., 2019).

The forum may be freely accessible or restricted; authors can identify themselves or remain anonymous. The notification allows those involved in the discussion forum to notify of new posts those participants who may be interested. The asynchronous version of online education is used mainly in the team education. It can be stated that the application of the asynchronous version is still low in corporate training.

The pandemic has opened up wider possibilities in using online forms of instruction in the form of live broadcasts with immediate feedback. Indeed, these forms of training have increased employees' interest in further professional training. It was also influenced by the fact that the full-time form was not feasible (to avoid the spread of the pandemic); moreover, a lot of employees are not interested in self-study. 
The forms of distance education implemented to date have mostly supported self-study. Information and communication technologies not only revived education through a number of videos and demonstrations, but also made it possible to improve the education process by the possibility of completing education from the comfort of our home. For many employees, live lectures with immediate feedback have become an important part of their lives during the pandemic. Online platforms available were used for education, which supplemented the time of work. The synchronous version of e-learning replaced full-time learning during the pandemic.

Opinions of respondents, i.e. personnel managers, line managers, and owners differ in the answers. Approximately one-third of respondents would prefer further corporate professional training to be implemented with a synchronous version of online training; some respondents considered the possibility of training even after working hours, which, of course, was refused by a number of employees.

If the manager wants to motivate their employees to participate in training, the training has to be held during working hours, even in the case of online education. The remaining two-thirds of respondents prefer the full-time form of education. The direct contact with the lecturer and also with other participants creates a certain respect and increases the interest and willingness to learn. At the same time, approximately $48 \%$ of respondents stated that a large part of employees, especially the young generation, are not able to learn independently. It was quite common and natural ten years ago to send study materials to employees to study, and that was followed by discussions and project meetings. This approach is of limited use today. One in ten employees will actually read the study material; one in fifteen will master it; and one in twenty will be able to use it in practice or develop it creatively. Another problem perceived by managers is the similarity of the synchronous version of online education to full-time education except for the need for classroom provision, which they evaluate very positively; however, the effect of education is significantly lower than that of full-time education.

Instructors and teachers often find that the learners leave from their laptops, smartphones, and other devices or perform other work activities during the learning/training process. As a result, education cannot meet the goals required. Despite the various online platforms that could actually fully replace full-time training, this seems unfeasible, given the employees' attitude to 
training. Information and communication technologies will most likely be used to attract attention and reduce fatigue in full-time education. Providing the possibility to choose forms of education for specific educational activities will very much depend on the participants in education and on their learning motivation.

E-learning represents a new philosophy of education, where the participant student has a central position, while the lecturer is moved to the background, and a facilitative approach in education is preferred. However, this approach can only be implemented if the learners are highly motivated to learn and see learning not only as a necessity, but relate it to their ambitions, interests, and aspirations. This form of education makes it possible to satisfy the study needs of heterogenous target educational groups. That, in turn, creates a precondition for the wide application of an open form of education: one in which anyone who is sincerely interested in a given issue can participate. E-learning is becoming an important innovative element in further professional business education. However, its use is limited by the interest and motivation of learners. Regarding the future development of education in terms of the relationship between traditional full-time education and distance education, we can only agree with the second Neubauer's principle of distance education (cited earlier in this paper) that it is not "in competition with traditional, campus-based classroom pedagogical techniques and orientations" (Neubauer, 2002, p. 4 $-5)$.

\section{Acknowledgement}

The research paper is a partial outcome from the nation-wide research project scheme VEGA No. 1/0328/21: 'Post-pandemic Business Management: identification of temporary and sustainable changes in sequential and parallel management functions in the context of the COVID-19 pandemic,' Faculty of Business Management, University of Economics in Bratislava, Slovak Republic; Project coordinator: Assoc. Prof. Ing. Juraj Mišún, PhD. 


\section{REFERENCES}

[1] Armstrong, M., \& Taylor, S. (2015). Řizení lidských zdrojů. Moderní ponětí a postupy. Praha: Grada Publishing.

[2] Arnold, D. N. (1997 - 2000). Computer-Aided Instruction, Microsoft ${ }^{\circledR}$ Encarta ${ }^{\circledR}$ Online Encyclopedia 2000. Availible at: http://encarta.msn.com

[3] Barták, J. (2015). Aktuální problémy vzdělávání a rozvoje zaměstnanců v organizacích. Praha: Univerzita Jana Amose Komenského Praha.

[4] Clark, R., \& Mayer, R. (2016). E-Learning and the Science of Instruction Proven Guidelines for Consumers and Designers of Multimedia Learning. Wiley Publishing.

[5] Cook, E. G. (2021). Learning Content Management Systems. Available at: https:// www.elucidat.com/blog/learning-content-management-systems/

[6] De Lima, D. P. R., Gerosa, M. A., Conte, T. U., \& de M. Netto, J. F. (2019). What to expect, and how to improve online discussion forums: the instructors' perspective. Journal of Internet Services and Applications, 10(1). https://doi.org/10.1186/s13174019-0120-0

[7] Elkins, D., \& PINDER, D. (2015). E-Learning fundamentals. Association for Talent Development.

[8] Encyclopedia Britannica. (n.d. ). "Correspondence education". Available at: https:// www.britannica.com/topic/correspondence-education

[9] European Commission. (2017). The European Framework for the Digital Competence of Educators (DigCompEdu). Available at: https://ec.europa.eu/jrc/en/digcompedu

[10] European Commission. (2019). The Digital Competences Framework for Citizens Digital competence framework 2.0. Available at: https://ec.europa.eu/jrc/en/digcomp/ digital-competence-framework

[11] European Commission. (2021). Shaping Europe's digital future. ICT for work: Digital skills in the workplace. Available at: https://digital-strategy.ec.europa.eu/en/library/ictwork-digital-skills-workplace

[12] Eurostat. (n.d.). Distributive trade statistics. NACE - Rev. Available at: https:// ec.europa.eu/eurostat/statistics-explained/index.php?title=Distributive_trade_ statistics_-_NACE_Rev._2

[13] Google. (2021a). Skype - free immediate messages and video calls. Available at: https://play.google.com/store/apps/details?id=com.skype.raider\&hl=sk\&gl=US

[14] Google (2021b). ZOOM Cloud meetings. Available at: https://play.google.com/store/ apps/ details?id=us.zoom.videomeetings\&hl=sk\&gl=US 
[15] Hrastinski, S. (2008). Defining Synchronous and Asynchronous Learning. EDUCAUSE Quarterly, 31(4), $51-55$.

[16] Hroník, F. (2007). Rozvoj a vzdělávaní pracovníků. Praha: Grada.

[17] Chajdiak, J. Štatistika jednoducho v Exceli. Bratislava: Statis, 2013.

[18] Irlbeck, S., \& Mowa, J. (2007). Learning Content Management System (LCMS). Available at: https://www.researchgate.net/publication/237334647_Learning Content_Management_System_LCMS

[19] Johnston, R. J. (2016). Computers in Education: An IBM Viewpoint. Educational Technology, 56(4), 56-58.

[20] Keegan, D. (2013). Foundations of distance education. London: Routledge.

[21] Krishnan, K., \& Rogers, S., P. (2015). Discussion Forums, in Social Data Analytics. Available at: https://www.sciencedirect.com/topics/computer-science/discussionforum

[22] Lee, J., \& Kim, M. (2020). Ceiling Priority for Synchronous Communication in RealTime Systems. In 2020 IEEE 4th Information Technology, Networking, Electronic and Automation Control Conference (ITNEC) (Vol. 1, pp. 617-622).

[23] Li, C., \& Lalani, F. (2020). The COVID-19 pandemic has changed education forever. This is how. World Economic Forum..

[24] Lockee, B. B. (2021). Online education in the post-COVID era. Nature Electronics, 4(1), 5 - 6. https://doi.org/10.1038/s41928-020-00534-0

[25] Masters, Y. (2021). Editor's introduction: COVID-19: Education Responses to a Pandemic. IAFOR Journal of Education, 9(2). https://doi.org/10.22492/ije.9.2

[26] Microsoft (2021). Microsoft Teams. Stretávajte sa, chatujte, volajte a spolupracujte na jednom mieste. Available at: https:/www.microsoft.com/sk-sk/microsoft-teams/ group-chat-software

[27] Mendíková, O. (2010). Lektorské dovednosti: Manuál úspěšného lektora. Praha: Grada.

[28] Mužík, J. (2011). Řizení vzdělávacího procesu. Andragogická didaktika. Praha: Wolters Kluwer.

[29] Neubauer, D. (2002). Three Principles of Distance Education. Educational Perspectives, $35(1), 4-5$.

[30] Pomffyová, M. (2009). E-learning - súčasný stav a perspektívy využitia technológií. Available at: http://www.efocus.sk/images/ uploads/e_learning.pdf

[31] Race, P. (1998). 500 Tips for Open and Flexible Learning. London: Kogan Page. 
[32] Trentin, G. (2010). Networked Collaborative Learning, Social Interaction and Active Learning. The pedagogical dimension.

[33] Veteška, J., \& Vacínová, T. (2011). Aktuální otázky vzdělávaní dospělých, Andragogika na prahu 21. století. Praha: Univerzita Jana Amose Komenského.

[34] Xu, M., David, J. M., \& Kim, S. H. (2018). The fourth industrial revolution: Opportunities and challenges. International Journal of Financial Research, 9(2), 9095.

[35] Zlámalová, H. (2008). Distanční vzdělávání a eLearning. Praha: Univerzita Jana Amose Komenského.

[36] Zoom.us. (2021). Zoom cloud meetings. Available at: https://hangouts.google.com/ 